\title{
Internal Control System Adoption Rate for Organic Rice Certification
}

\author{
Suswadi ${ }^{*}$, Agung Prasetyo, Ratih Dwi Kartikasari, and Kusriani Prasetyowati \\ Agribusiness Study Program, Faculty of Agriculture, Tunas Pembangunan University \\ Jl. Balekambang No 01 Manahan, Surakarta, Central Java, Indonesia
}

\begin{abstract}
The ICS system has been developed to facilitate the work of organic farmers and ICS officers in the field. This study aimed to analyze the level of ICS innovation adoption at APPOLI (Organic Farmers Association) Boyolali Regency and analyzed the factors that influence farmers' decisions in implementing the ICS system. Determination of respondents used the Proportionate Stratified Random Sampling technique. The model uses maximum likelihood estimation (MLE) to measure the determinants that influence the adoption of ICS innovations. The results showed that the adoption rate of ICS innovation farmers within one year has reached $83.33 \%$ of all respondents. Estimation of parameters using logit model regression analysis. From the results of the Wald test, it can be seen that the independent variables that have a significant effect on the acceleration of the adoption of ICS innovation were the age of the respondent (X1), education (X2), the distance from the house to the market (X5), the level of income (X7), and network availability (X8). Facilitation and assistance in using ICS to the farmer can be continued and network reinforcement is needed considering that there is only a single operator capable of reaching the location of organic rice farming.
\end{abstract}

\section{Introduction}

Based on AOI [1] the area of organic land in Indonesia tends to increase by $21.36 \%$ from 2014 to 2015. This area includes organic farming, aquaculture, and wild harvest areas which are the result of the compilation of certified areas, in the certification process, PAMOR certification, and without certification. The certified organic land area is $30.57 \%$ of the total organic land which reaches $79,833.83 \mathrm{Ha}$ and is divided into four types, namely land that has been managed organically, land in the conversion period to organic farming, land for harvesting wild products (palm sugar and honey), and aquaculture.

An organic farming system is a holistic farming system in which production management aims to improve the health of agroecosystems including biodiversity, biological cycles, and soil biological activities to optimize crop production [2]. The certification of organic products produced includes storage, processing, post-harvest, and marketing and must comply with the standards set by the standardization body. A healthy lifestyle has become a new lifestyle and has been institutionalized internationally which

${ }^{*}$ Corresponding author: suswadi slo@yahoo.com 
requires guarantees that agricultural products must be safe for consumption, high nutritional content, and environmentally friendly [3].

ICS (Internal Control System) is a quality assurance system that must be owned by every organic producer. ICS supervision is carried out more strictly and periodically in summarizing farmers' commitments, carrying out internal inspections and field counseling for farmers, carrying out internal approval mechanisms and handling non-conformities, carrying out farmer documentation and farm data, to monitoring product flow. This aims to support the sustainability of organic certification. ICS will generally coordinate with ECS to determine organic farming certification. Documents that must be recorded by ICS officers are generally very numerous and varied, including data on farmer groups consisting of (a) farmer group structure, (b) farmer group SOPs, and (c) recapitulation of the area of fertilizer use. The structure contains the farmer groups and their members who are registered as official members. The data for ICS management includes (a) organizational guidelines, (b) internal inspection results data, and (c) organizational structure. The ICS organizational guidelines contain: (a) internal organic standards, (b) farmer registration and supervision procedures, and (c) violations and sanctions. In addition, the approval commission also prepares a request letter for external inspection to the certification body. Based on the results of the internal inspection, data obtained from the approval farmer list (AFL) land area that has been approved to take part in organic farming certification.

The number of documents that are many and varied so far is still being collected and recorded manually. Recording with a manual system is felt to be less practical and must require a large space for storing documents recorded by ICS officers. The manual recording also causes difficulties in finding and opening files during quality document audits. The certification process starts from an application by a certification applicant to an organic certification body (LSO), then the LSO audits documents and conducts land inspections so that later it can be decided whether certification can be granted to the applicant or not. ICS online is expected to facilitate the work of ICS officers in recording, storing, documenting, and archiving ICS activities in the field. ICS online is also expected to be able to assist the performance of certification bodies in carrying out quality audits and completing quality documents when submitting organic agriculture certification.

Referring to several facts above, the study was conducted to determine the level of adoption of online ICS in APPOLI, Boyolali Regency, and to determine the factors that influence farmers' decisions in implementing the Online ICS system. ICS online is a newly formed system and has never existed before, so the factors that influence the decision to adopt online ICS innovations are important for the development of the next program.

\section{Method}

The location of the research was determined by purposive sampling, namely in the APOLLI Member Farmers Group (Boyolali Regency Organic Farmers Association). The research was conducted in Boyolali because the ICS Online application program has been socialized and has been running for more than a year. The time of the study was carried out from June 2019 - June 2020. The basic method used in this study was descriptive-analytical. Determination of respondents using the Proportionate Stratified Random Sampling technique with 30 respondent [4] [5], namely the determination of respondents based on the target group or users of ICS Online technology. The data collected in this study include primary data and secondary data. Primary data were obtained directly from farmers through interviews using a list of questions (questionnaires). While secondary data was obtained from BPS Boyolali Regency.

The model uses Maximum Likelihood Estimation (MLE) to measure the determinants that affect the adoption of ICS innovations. The logit model was chosen because the model 
has a sensor distribution if it has a zero value for farmers who do not adopt the online ICS innovation. Logistic regression is often used in solving classification problems in parametric methods. This method is used to describe the relationship of the dependent variable (response variable) with the independent variable (predictor variable) which is categorical, continuous, or a combination of both. To draw the conditional mean of $\mathrm{Y}$ (response) to $\mathrm{X}$ (predictor) the calculation $(\mathrm{x}) \mathrm{E}(\mathrm{Y} \mathrm{x})$ is used. The form of the logistics model is as follows:

$$
\pi(x)=\frac{\exp \left(\beta_{0}+\beta^{\prime} x\right)}{1+\exp \left(\beta_{0}+\beta^{\prime} x\right)},
$$

where $\beta^{\prime}=(\beta 1, \beta 2, \ldots, \beta p)$ and $X=(x 1, x 2, \ldots, x p), p=$ number of parameters. By using the logit transformation of $(\mathrm{x})$, the logistic model can be called the Logit Model which is shown by:

$$
g(x)=\ln \left\{\frac{\pi(x)}{1-\pi(x)}\right\}=\beta_{0}+\beta_{1} x_{1}+\beta_{2} x_{2}+\ldots+\beta_{p} x_{p}=\sum_{j=1}^{p} \beta_{j} x_{j}
$$

In multiple linear regression it is assumed that $\mathrm{Y}=(\mathrm{x})+\varepsilon$ where $\varepsilon$ is an error and shows the difference between the observed object and the expected value. The error is assumed to be normally distributed with zero mean constant variance for the observed variables. So with a binary response stated, if $\mathrm{Y}=0$, then $\varepsilon=-\pi(x)$ with probability $1-\pi(\mathrm{x}), \mathrm{Y}=1$, then $\varepsilon=1-\pi(\mathrm{x})$ with probability $\pi(\mathrm{x})$. And it can be stated that $\varepsilon$ has $\mathrm{E}(\varepsilon)=0$ and $\operatorname{var}(\varepsilon)=\pi$ (x). $[1-\pi(\mathrm{x})]$ which follows the binomial distribution. Estimation method used to estimate unknown parameters is maximum likelihood estimation (Maximum Likelihood Estimation or MLE) by setting the assumption of Bernoulli distribution and independent observation object, $E(\varepsilon i, \varepsilon j)=0, \mathrm{i} \neq \mathrm{j}$. In pairs of observations (xi,yi), the maximum likelihood function is

$$
\varsigma(x i)=\pi(x i) y i[1-\pi(x i)] 1-y i
$$

The general formula is always given in the form of an index function as follows

$$
\begin{aligned}
& \mathrm{yi}^{*}=\mathrm{Xi}+\mathrm{ei} \\
& \mathrm{yi}=0 \text { if } \mathrm{yi}^{*}<0 \\
& \mathrm{yi}=\mathrm{yi}^{*} \text { if } \mathrm{yi}^{*}>0
\end{aligned}
$$

where yi is the proportion of index variable number of respondent $\mathrm{i}$; $\mathrm{Xi}$ is the path vector of the dependent variable; ei is independent y and distributed residuals with zero mean value and variance ó 2 : is a vector known as the MLE tobit coefficient. The problem will be to guess and 2 with the availability of information from Y and Xi. [6]. In the case of zero values in the observations of several respondents in the sample, it is highly recommended to use the Logit Model. If in the Logit model there is a negative $y^{*}$ value, in principle it must be included in the estimate; but due to encoring, this will not be done. So the value of zero is the result of observation. These variables, in principle, are assumed to be negative values. Observation of the zero value is not due to censoring, but because of farmers' decisions. In this case, the right procedure will make the decision model produce a zero observation value rather than using the Logit procedure [7]. By estimating the coefficients, it is possible to measure the impact of a change of one standard deviation in the value of the independent variable on the dependent variable. Marginal effect refers to the estimate of the coefficient given by changes in y on all variables above the limit, measured by the probability of being above the limit, and the probability of a change above the limit being measured by the average value (mean). The possible intensity of adoption of innovative practices for rice cultivation, plantations and animal husbandry are as follows: 


$$
E\left(y i^{*}\right)=X F(z)+o f f(z)
$$

Where $X$ is vector of independent variables; $F(z)$ is cumulative normal distribution of $(\mathrm{z})$; $\mathrm{f}(\mathrm{z})$ is the value of the derivative of the normal curve at the point obtained; $\mathrm{Z}$ is $\mathrm{Z}-$ value for the normal curve area; $E$ is vector of Logit maximum likelihood estimate; and ó is standard error for the error value.

The marginal effect of the independent variable on the expected value of the dependent variable [8] is described as follows:

$$
E\left(y i^{*}\right) / o ́ X i=F(z) i
$$

The change in the probability of adopting an innovation as a dependent variable is as follows:

$$
F(z) / X i=f(z) \text { i/ } o
$$

and, the change in intensity (if adoption refers to a change in an independent variable among adopting farmers) is described as follows:

$$
E(y i *) / o ́ X i=\hat{a} I\{1-z f(z) / F 9 z)-f(z) 2 / F(z) 2\}
$$

Logit analysis will be used in this study to determine the adoption of an online ICS system to support organic rice certification in Boyolali Regency.

$$
\begin{gathered}
\operatorname{Ln} \frac{P i}{1-p}: \alpha+\sum_{j=1}^{n} \beta X i+e i \\
: a+b 1 \operatorname{LnX} 1+b 2 \operatorname{Ln} X 2+b 3 \operatorname{Ln} X 3+b 4 \operatorname{Ln} X 4+b 5 \operatorname{Ln} X 5+b 6 \operatorname{Ln} X 6+ \\
b 7 \operatorname{Ln} X 7+b 8 \operatorname{Ln} X 8+b 9 \operatorname{Ln} X 9+b 10 \operatorname{Ln} X 10+b 11 \operatorname{Ln} X 11+e
\end{gathered}
$$

where $\mathrm{LnY}$ is Acceleration of adoption, expressed in binary units of 1 or 0 ( 1 adoption < 1 year; $0=$ adoption $>1$ year); LnX1 is Age (years); LnX2 is Education (years); LnX3 is Number of dependents (person); LnX4 is Land Area (Ha); LnX5 is Distance from house to market (km); LnX6 is Distance from house to sub-district $(\mathrm{Km})$; LnX7 is Farming Income (Rp); LnX8 is Mobile Network (per day of the year); e is disturbance term or disturbing factor (error); $a$ is constant and bi is regression coefficient $(i=1,2,3, \ldots, 8)$.

The suitability test (goodness of fit model) used the Hosmer and Lameshow test in the model. The coefficient of determination test was also carried out by looking at the value of Nagelkerke R square. Test the whole model and test the variables partially using the Omnibus Tests of Model Coefficients test and Wald's test [9].

\section{Result and Discussion}

\subsection{Characteristic of Farmer Household}

Table 1. Identity of ICS online sample of 30 farmers in Boyolali

\begin{tabular}{|c|l|c|}
\hline No & \multicolumn{1}{|c|}{ Description } & Average \\
\hline 1 & Age of sample farmers (years) & 44.13 \\
\hline 2 & Education (years) & 9.16 \\
\hline 3 & Number of dependents (person) & 3 \\
\hline 4 & Farming experience (years) & 9.63 \\
\hline 5 & Area of land for farming (Ha) & 0.63 \\
\hline
\end{tabular}


The identity of the sample farmers provides an overview of the condition of the farmers as one of the important factors in farming. Farmers in a farm are managers who plan, organize, implement and evaluate a production process. The identity of the sample farmers in this study included age, length of education, number of family dependents, experience in farming and area of arable land.

The results of the analysis show that the average age of the sample farmers is 44.13 years, which means that they are still of productive age. The average length of education they received was 9.16 years, this indicates that most of the sample farmers were junior high school graduates. The level of education will affect a person's knowledge and ability to accept innovation and renewal of administrative system knowledge. The average number of dependents of a farming family is 3 people. The experience of the sample farmers in organic rice farming has been quite long, with an average of almost 9.63 years. This long experience influences the attitude of farmers in making decisions related to farming and the courage to take risks. The land is a production factor that is necessary for doing farming. The average land area for organic rice farming owned by this sample farmer is $0.63 \mathrm{Ha}$. Land ownership will affect production yields, farmers' incomes and have an impact on efforts to transfer and apply technology. If land tenure is narrow, agricultural development efforts will be difficult [10].

\subsection{Area Accessibility}

Regional accessibility is a key factor that has an important role in supporting or hindering the success of rice farming. Regional accessibility indicators in the research location are determined, among others, by the distance from the respondent's house to the market and sub-district sources.

The results of field observations show that the accessibility of the area is quite good, marked by the relatively close distance from the respondent's house to the location of organic rice farming activities. Most of the road conditions are still dirt and cast concrete, but four-wheeled vehicles can still pass. The accessibility of rice farming locations to the road is generally conducive, thus facilitating the transportation of organic rice inputs and outputs. The accessibility of this location can reduce transportation costs thereby increasing cost efficiency. The average distance that must be traveled from the settlement to the public market as a place to sell products is $5.08 \mathrm{~km}$. The average distance between the respondent's house and the sub-district is $6.33 \mathrm{Km}$. The sub-district is a place that provides information and fulfills the needs of innovation needed by farmers to improve their farming performance. The distance is not too far allows the flow of information to run more smoothly.

\subsection{Online ICS Adoption Rate}

ICS or internal control system is an internal control unit for farmer groups that is useful for recording, documenting, and archiving every type of activity carried out by organic rice farmers. So far, ICS is still implementing a manual filing system, causing the number of files to accumulate and the risk of losing farmer activity records. The requirements for organic rice certification require that farmers' documents are complete and properly stored so that when they come to the inspection process on organic farmland by the certification agency, farmers can show a record of activities that have been carried out properly. The inspection process becomes easier and smoother.

The organic farming ICS team consists of Registration Team, Approval Team, Internal Inspection Team, and Assistance Team. The internal inspection team performs crossinspection so that there are no interest groups that can undermine the overall integrity of the 
ICS. The main task of the Inspection team is to carry out organic assessment activities for rice products, receive and accommodate: inputs, complaints from members, record and report violations in farmer groups, report inspection results to the team for evaluation. This activity is carried out regularly and makes it easier for farmers to apply the habits that are the key to organic farming.

Farmers who have implemented ICS Online within one year have reached $83.33 \%$ of the 30 respondents. This figure is expected to be $100 \%$ in the second year of implementation of innovation provision. ICS online within one year is adjusted to the implementation of the audit by the certification body. The ease of use of the application has a significant effect on the user and consumer trust. Ease of administration is the main requirement that must be met in the application of ICS Online. ICS online aims to simplify and minimize data loss considering the large number of documents that must be recorded and archived by ICS officers.

Document preparation is carried out by the ICS manager. This document is evidence of a detailed description of the Unit Operational Procedures (SOPs) that have been implemented by ICS and farmers. The documents prepared are: (a) a map of the area, (b) data on farmers/farmer group association registration results, (c) data on results of internal inspections, and (d) documentation of decisions from the organic approval commission. The regional map presents data on the expansion of organic rice that will be submitted for external inspection which includes: land address, land sketch, and conditions around the land (direction, landowner, rivers, irrigation canals, roads, other permanent buildings). The history of the land is presented as a source of information on land use in the previous several growing seasons and to find out whether the land can be classified as organic agricultural land or is in the conversion period. Inspection and certification forms are included as evidence when smallholders apply for internal inspections to ICS.

Farmer group data prepared are: (a) farmer group structure, (b) farmer group SOP, and (c) recapitulation of fertilizer use area. The structure contains the farmer groups and their members who are registered as official members. The data for ICS management includes (a) organizational guidelines, (b) internal inspection results data, and (c) organizational structure. The ICS organizational guidelines contain: (a) internal organic standards, (b) farmer registration and supervision procedures, and (c) violations and sanctions. In addition, the approval commission also prepares a request letter for external inspection to the certification body. Based on the results of the internal inspection, data obtained from the approval farmer list (AFL) land area that has been approved to take part in organic farming certification.

\subsection{Factors Affecting the Adoption of ICS Online Innovation}

Based on Table 2, the Model Significance value is 0.034 , this value is smaller than $5 \%$, it can be concluded that the independent variables used together to affect the speed of adoption of online ICS innovation or at least one independent variable has a significant effect on the speed of innovation adoption [11]. ICS Online. Table 2. Also shows that the model by including eight independent variables has a change in parameter estimation (-2 log-likelihood) of 15.949 . If we look at the R-square value of 0.426 or $42.6 \%$ (Cox \& Snell) and 0.643 or $64.3 \%$ (Nagekerke) which shows the variables of the respondent's age, education level, number of family dependents, land area, distance from house to market, distance houses to sub-districts, farmers' income and the availability of cellular networks provide the proportion of understanding on the adoption of ICS Online innovation can be explained by the model by $64.3 \%$, while the remaining $35.7 \%$ is explained by other factors outside the model. The Hosmer and Lemeshow test was used to determine the suitability of the logit equation model [12]. The results showed that a significance value of 0.332 was 
greater than $5 \%$ so that the model had adequately explained the data and met the goodness of fit criteria.

Table 2. Coefficient of ICS Online Adoption Variables Logit Model Regression

\begin{tabular}{|l|c|c|c|c|r|}
\hline & Bi & SE & Wald & sig & Exp (B) \\
\hline Age** & -12.146 & 9.570 & 1.611 & 0.024 & 0.039 \\
\hline Education* & 1.371 & 3.521 & 0.152 & 0.097 & 3.941 \\
\hline $\begin{array}{l}\text { Number of } \\
\text { Family }\end{array}$ & -8.434 & 6.793 & 1.541 & 0.214 & 0.000 \\
\hline Land Area & -1.104 & 1.472 & 0.562 & 0.454 & 0.332 \\
\hline $\begin{array}{l}\text { Distance to } \\
\text { market* }\end{array}$ & -50.230 & 37.488 & 1.795 & 0.080 & 0.541 \\
\hline $\begin{array}{l}\text { Distance to } \\
\text { sub district }\end{array}$ & 38.298 & 32855 & 1.359 & 0.244 & 4.290 \\
\hline $\begin{array}{l}\text { Income } \\
\text { Level* }\end{array}$ & -2.418 & 1.737 & 1.938 & 0.064 & 0.089 \\
\hline $\begin{array}{l}\text { Network } \\
\text { aviability* }\end{array}$ & -1.306 & 0.983 & 1.766 & 0.084 & 0.271 \\
\hline Constant & 109.125 & 106.549 & 1.049 & 0.036 & $2.467 \mathrm{E}+047$ \\
\hline Omnibus Tests of Model Coefficients & & 0.034 & \\
\hline Cox \& Snell R Square & & 0.426 & \\
\hline Nagelkerke R Square & & 0.643 & \\
\hline -2 Log likelihood \\
\hline
\end{tabular}

Information:**) significant at $5 \%, *$ ) siginificant at $10 \%$

Parameter estimation using logit model regression analysis is shown in Table 2. From the results of the Wald test, it can be seen that the independent variables that significantly affect the acceleration of adoption of ICS Online innovation at a significant level of $5 \%$ are the age of the respondent (X1). While at the $10 \%$ level of significance, the variables that have a significant effect on the adoption of the online ICS system are education level (X2), distance from home to market (X5), income level (X7), and network availability (X8). While the variables that have no significant effect are the number of dependents of the family (X3), land area (X4), and the distance from the house to the sub-district (X6).

From the value of the odds ratio (Exp B) in the logit model regression, found variables that have a significant effect on the acceleration of online ICS adoption are 0.039 for farmer age, 3.941 for respondent education level, 0.541 for accessibility to the nearest market, 0.089 for farm income and 0.271 mobile network availability. The value of the odds ratio of 0.039 on the respondent's age variable is an indication that if farmers are given time to continue using ICS online, in one year it will accelerate by 0.039 times. This speed is considered very slow due to the increasing age or age of nature to change the mindset towards innovation becomes increasingly difficult. Increasing age also makes a farmer who is now still in his comfort zone enjoying the results of farming that is now certified. The notion that the old ICS methods are still effective for certification often hinders changes to the implementation of ICS Online.

The education level variable has an odds ratio value of 3.941, meaning that if farmers continue to be equipped with ICS Online knowledge, the tendency (opportunity) to accelerate the adoption of ICS Online will increase by about 3.941 times from before each time they are provided with knowledge. Knowledge provision is an important factor because understanding the importance and usefulness of ICS Online will be easily accepted by farmers so that it is effective to implement. Farmers who have an open attitude to change 
will easily interact with changes in the ICS system. Experience in managing farming activities will shape farmers' attitudes towards the integrated farming innovations introduced. Various factors that influence the formation of attitudes are personal experience, culture, other people who are considered important, the mass media, educational institutions, and religious institutions, as well as emotional factors within the individual. Attitudes obtained through experience will have a direct influence on subsequent behavior [13].

The value of the odds ratio on accessibility to the nearest market which is 0.541 means that every $1 \mathrm{~km}$ distance reduction (closer) from the location of the farmer's settlement to the market has the opportunity to increase the acceleration of ICS Online adoption by 0.541 times faster. The existence of a more certain market raises expectations for the fulfillment of business capital needs, marketing, and technical guidance in a positive way. The hope of farmers at the beginning of following the partnership pattern is that there will be more secure marketing, capital loans, and technical development of cultivation as well as more adequate input markets. Proximity to the market will ensure farmers always update the latest information on market information. ICS Online is an advantage that other organic rice producers do not have, let alone conventional rice producers. Positive stigma will stimulate farmers to immediately adopt the adoption of online ICS innovations because it adds a good image to farmers.

The value of the odds ratio of 0.089 for farm income means that an increase of one rupiah against farmers' income will increase the speed of ICS Online adoption by 0.089 times. An increase in income will increase the purchasing power of farmers towards consumer goods. Innovation is something related to goods, services, or ideas that are perceived as new by someone. Although the idea has been around for a long time this can be said to be an innovation for people who have just seen or felt it. The implementation of ICS Online certainly requires technological equipment that was previously not owned or used by farmers. Procurement of this technology requires several expenses taken from the income of organic rice farmers. Equipment such as cellphones, laptops, and the internet is mandatory when the ICS Online system is implemented.

The value of the odds ratio of 0.271 for the availability of cellular networks means that cellular networks are increasingly reaching the respondent's area. Opportunities to accelerate innovation adoption are about 0.271 times faster. The online system will depend heavily on the availability of the cellular network. At the research location, there are still some areas that can only use one internet service, the provider operator. This online system becomes very dependent on the network quality of the single operator. The online system is easier to implement and does not require a large investment both at the start and during operation. It only requires a good internet connection as initial capital to build this online business. The nature of online activities which is very dynamic and demands rapid changes requires the right reaction and steps so that a product or service can survive and win the competition to become an important tool and begin to be taken seriously [14]. Online ICS system activities must be able to answer the challenges of ease and reliability when compared to manual ICS systems.

The number of dependents, land area, and distance to the sub-district capital did not affect the speed of adoption of ICS Online innovation. The number of dependents will burden farmers in farmer household expenses. Large expenses will make farmers unable to buy equipment for ICS online. This result is also supported by farmers' income which has a significant effect on the implementation of ICS online, meaning that farmers do not see their family dependents but because they see the importance and usefulness of online ICS, farmers set aside a part of their income to fulfill the equipment used in ICS Online. The area of land does not have a significant effect because the online system makes farmers who have narrow, medium, and wide land equally likely to adopt the innovation of the ICS 
Online system because of the common need for organic farming certification. This statement is not following statement [15] which states that the wider the land tenure, the faster it is adopted because it has a better economic capacity. The distance to the subdistrict does not affect the speed of innovation adoption because organic farming is independent of government policies and government institutions which generally regulate rice problems in general (conventional rice. This privatization makes organic farming independently more capable of being explored widely. The results of this study This is contrary to the findings [16] which states that the acceleration of innovation adoption is significantly influenced by the distance from the settlement to the farm location, the distance from the settlement to government facilities, and the distance from the settlement to the technology source. The slowdown in adoption is influenced by the dependents of the family, the distance from the settlement to the farm location, the distance from settlement to sources of capital, and the distance of settlements to sources of technology [17].

\section{Conclusion}

Based on the results of data analysis, it can be concluded that the speed of adoption of online ICS innovations is quite high, at 83.3 percent. Factors that affect the speed of adoption of online ICS system innovations are the age of the respondents, education level, distance from home to market, income level, and availability of cellular networks.

\section{References}

1. Aliansi Organis Indonesia [AOI]. Statistik Pertanian Organik Indonesia. (Aliansi Organis Indonesia, Bogor, 2016).

2. I.W. Budiasa. Asian Jurnal of Agriculture and Developmet. 11(1), 65-75 (2014)

3. L.A. Dewi, I.G.A.A. Ambarawati, I.W. Budiasa. Jurnal Manajemen Agribisnis. 4(1), 37-46 (2016)

4. B. Prasetyo and L.M. Jannah. Metode Penelitian Kuantitatif. (Rajawali Pers, Jakarta, 2011)

5. B. Prasetyo and L.M. Jannah. Metode Penelitian Kuantitatif. (Rajawali Pres, Jakarta, 2011)

6. J.F. Mc Donald and R.A. Moffitt. The Uses of Tobit Analyis, The Review of Economics and Statistics 62 (2): 318-321 (1980)

7. G.S. Maddala. Introduction to Ecometrics. (Mac Millan Publishing Company, New York, 1989)

8. J.F. Mc Donald and R.A. Moffitt. The Uses of Tobit Analyis, The Review of Economics and Statistics. 62 (2), 318-321 (1980)

9. S, Dian. Jurnal Visi Komunikasi. 16(1), 71 - 90 (2017)

10. A.A. Andrias, Y. Darusman and M. Ramdan. Jurnal Ilmiah Mahasiswa Agroinfo Galuh. 4(1), 521-529 (2017)

11. G.S. Maddala. Introduction to Ecometrics. (Mac Millan Publishing Company, New York, 1989)

12. Tobin, J. 1958. Estimation of relationships for limited dependent variables. Econometrica. 26, 24-36 (1958)

13. A.A. Andrias, Y. Darusman and M. Ramdan. Jurnal Ilmiah Mahasiswa Agroinfo Galuh. 4(1), 521-529 (2017) 
14. K.S. Indraningsih. Jurnal Agro Ekonomi. 29(1), 1-24 (2011)

15. D. Sarastuti. Jurnal Visi Komunikasi.16(1), 71 - 90 (2017)

16. T. Mardikanto. Redefinisi dan Revitalisasi Penyuluhan Pertanian. (Pasca Sarjana UNS, Surakarta, 2017)

17. R. Burhansyah. Informatika Pertanian. 23(1), 65 - 74 (2014) 